\title{
ANALISIS SISTEM MANAJEMEN PEMBELAJARAN TATAP MUKA PADA MASA PANDEMI COVID-19 DI SMA KRISTEN RANTEPAO
}

\author{
Hendrik Palinggi ${ }^{1}$,Witarsa Tambunan ${ }^{2}$ \\ ${ }^{1}$ Mahasiswa Magister Administrasi Pendidikan PPs-UKI, Jakarta, Indonesia, ${ }^{2}$ Dosen Magister \\ Administrasi Pendidikan PPs -UKI, Jakarta Indonesia \\ e-mail: witarsa.oke@gmail.com
}

\begin{tabular}{l|l|l} 
Received : Januari, 2021 & Accepted : Januari, 2021 & Published : Januari, 2021
\end{tabular}

\begin{abstract}
The objectives of writing this study were to: 1) to obtain the best methods and techniques in the limited face-to-face learning management system in Rantepao Christian Senior High School; 2) contributing advice to the school management team in order to improve the quality of learning during the Covid 19 pandemic; 3) contributing advice to educators and education personnel in order to improve face-to-face learning management during the COVID-19 pandemic. The method used in this writing is a qualitative method with a literature review approach and participant responses via google form to students and teachers at Rantepao Christian High School. In the analisis using the problem tree approach, target tree, and alternative solution tree in getting the expected results. The results show that the impact of a learning management system that is suitable for school conditions can provide time-effective and cost-efficient convenience for students and teachers in achieving learning objectives.
\end{abstract}

Keywords: learning management, face-to-face learning, Covid-19 pandemic

\begin{abstract}
Abstrak
Tujuan penelitian ini untuk: 1) memperoleh metode dan teknik terbaik dalam sistem manajemen pembelajaran tatap muka terbatas di SMA Kristen Rantepao; 2) menjadi sumbang saran kepada tim majemen sekolah dalam rangka perbaikan mutu pembelajaran selama pandemi covid 19;3) menjadi sumbang saran kepada tenaga pendidik dan tenaga kependidikan dalam rangka perbaikan manajemen pembelajaran tatap muka selama pandemik covid 19. Metode yang digunakan dalam penulisan ini adalah metode kualitatif dengan pendekatan literatur review dan respon partisipan lewat google form kepada siswa-siswi dan guru-guru di SMA Kristen Rantepao. Dalam analisis memamfaatkan pendekatan pohon masalah, pohon sasaran, pohon solusi/alternatif dalam mendapatkan hasil yang diharapakan. Hasilnya menunjukkan bahwa dampak sistem manajemen pembelajaran yang sesuai kondisi sekolah dapat memberikan kemudahan, waktu yang efektif, dan biaya yang efisien bagi siswa dan guru dalam pencapaian tujuan pembelajaran.
\end{abstract}

Kata Kunci: manajemen pembelajaran, pembelajaran tatap muka, pandemic covid 19

\footnotetext{
Citation: Palinggi, H., \& Tambunan, W. (2021). ANALISIS SISTEM MANAJEMEN PEMBELAJARAN TATAP MUKA PADA MASA PANDEMI COVID-19 DI SMA KRISTEN RANTEPAO . Jurnal Manajemen $\begin{array}{llll}\text { Pendidikan, 10(1), } & \text { 21-27. } & \text { Retrieved } & \text { from }\end{array}$ http://ejournal.uki.ac.id/index.php/imp/article/view/3263
} 


\section{PENDAHULUAN}

Wabah virus covid-19 telah berlangsung lebih setahun dan belum ada tanda-tanda wabah akan berakhir. Menurut WHO, ada 200 negara yang terkonfirmasi terdampak wabah virus covid-19, tak terkecuali Indonesia. Hampir seluruh sektor kehidupan terkena dampak wabah virus covid-19, termasuk sektor pendidikan yang merupakan sektor yang paling terasa. Anak-anak harus belajar dari rumah dan guru-guru harus mengajar dari rumah sehingga tidak ada interaksi dengan baik yang akan berdampak pada mutu pendidikan. Pemerintah melalui Kemdikbud menerapkan kebijakan belajar dari rumah (BDR) untuk satuan pendidikan yang berada di wilayah zona kuning, oranye, dan merah. Sedangkan bagi satuan pendidikan yang berada di zona hijau, dapat melaksanakan pembelajaran tatap muka terbatas dengan tetap memperhatikan protokol kesehatan.

SMA Kristen Rantepao melakukan tatap muka terbatas sejak minggu pertama bulan september 2020 dengan sistem 2 shif, setiap shif ada 15 sampai 18 siswa yang berada di dalam satu kelas. Jam tatap muka 120 menit perhari dibagi dalam dua jam pelajaran, sehingga tiap mata pelajaran berlangsung 60 menit. Dalam setiap pembelajaran tatap muka di masa pandemi kendala yang dihadapi adalah durasi waktu yang panjang untuk guru dan durasi waktu yang pendek untuk peserta didik akibat dari pembagian shif setiap kelas. Kendala lainnya jika pembelajaran campuran tatap muka - online atau sistem blanded learning adalah infrastruktur di sekolah belum memadai dan kesiapan guru menggunakan alat pendukung lainnya belum memadai. Kendala-kendala tersebut akan berpengaruh terhadap mutu pendidikan di SMA Kristen Rantepao. Dengan memperhatikan kendala-kendala di atas maka dengan penuh kesadaran yang tinggi dari guru-guru dan tim menajemen sekolah harus mencarikan solusi terbaik untuk mengatasi kendala-kendala yang dihadapi selama proses pembelajaran tatap muka terbatas selama pandemi covid 19. Dengan memperhatikan kondisi-kondisi real yang ada di SMA Kristen Rantepao, salah satu langkah yang tepat dilakukan pihak sekolah adalah memperlakukan sistem manajemen pembelajaran campuran, yaitu sistem pembelajaran tatap muka terbatas guna menjelaskan materi-materi ajar yang sulit dijelaskan lewat platform-platform pembelajaran tatap muka online seperti Google Meet, Zoom, atau Teams. Sedangkan untuk admistrasi pembelajaran seperti penggiriman ataupun pengumpulan tugas, dan tanya jawab ataupun sharing materi, serta evaluasi dapat dengan muda dilaksanakan di google classroom ataupun moodle. Sistem pembelajaran campuran seperti ini belum semua guru melakukan di SMA Kristen akibat keterbatasan dalam penguasaan TIK dengan baik.

Dalam proses pembelajaran tatap muka terbatas memerlukan pengelolaan pembelajaran yang baik. Kata pengelolaan sepadan dengan kata manajemen yang berasal dari bahasa inggris "Managaments", yang berarti tata laksana dan tata pimpinan. Erwinsyah, A. (2017:71), "pengelolaan adalah proses perencanaan, pengorganisasian, kepemimpinan, dan pengendalian semua sumber daya organisasi untuk mencapai tujuan yang telah ditetapkan". Pengertian sistem manajemen pembelajaran adalah salah suatu cara untuk mengatur aktivitas pembelajaran berdasarkan prinsip pembelajaran bermakna guna mencapai tujuan pembelajaran sehingga dapat tercapai secara efisien dan efektif. Efisien mengandung pengertian proses yang dilakukan untuk menghemat sumber daya seperti menghemat tenaga, waktu, dan biaya, sedangkan efektif mengandung pengertian hasil yang sesuai harapan. Fakhrurrazi, F. (2018:92), "untuk menciptakan kondisi pembelajaran yang efektif, guru dituntut agar mampu mengelola proses pembelajaran yang memberikan rangsangan kepada siswa sehingga ia mau dan mampu belajar secara aktif. Dari pengertian di atas dapat disintesakan bahwa manajemen pembelajaran yang baik merupakan situasi yang diciptakan guru dan sekolah yang memungkinkan siswa dapat secara aktif memperoleh pengetahuan dari berbagai sumber belajar.

Guru yang efektif akan mempertimbangkan kebutuhan pebelajar, mengorganisasikan dan mengelola kelas dengan baik, menyediakan sumber-sumber dan bahan pembelajaran yang sesuai, dan membimbing pebelajar dalam kegiatan pembelajaran. Hal ini tidak terlepas dari sumber daya

Hendrik Palinggi, Witarsa Tambunan 
manusia, Darmawati. Y.S (2013:2) "pendidikan disebut bermutu dari segi proses jika proses belajar mengajar berlangsung secara efektif, peserta didik mengalami proses". Untuk mendapat guru yang bermutu sangat diperlukan pengembangan kompetensi guru secara berkesinambungan lewat pelatihan-pelatihan yang berkaitan dengan kompetensi pedagogik guru. Guru merupakan faktor penentu tinggi rendahnya kualitas hasil pendidikan di sekolah. Menurut Nadeak B. (2019:103), "guru memegang peranan yang amat strategis serta memiliki tanggung jawab yang besar terhadap keberhasilan proses pendidikan itu sendiri". Dari uraian ini dapat katakan bahwa kemampuan guru dalam mengelola pembelajaran memegang peran yang amat strategis dalam peningkatan mutu pembelajaran di sekolah.

Pada masa pandemi covid 19, manajemen pembelajaran terasa sangat sulit akibat terlalu banyak kendala-kendala seperti waktu yang sangat terbatas, media belajar yang belum dimaksimalkan, kemampuan TIK guru masih kurang, sarana dan prasarana yang belum memadai di sekolah. Kendala-kendala seperti ini menjadi perhatian semua pihak di sekolah sehingga tidak terjadi kemerosotan mutu pendidikan lebih dalam. Belajar secara tatap muka terbatas di dalam kelas sangat diperlukan guru untuk berinteraksi secara langsung dengan siswa agar hubungan emosional guru dan siswa tetap terjalin dengan baik. Lewat pembelajaran tatap muka di dalam dapat diperoleh mamfaat lebih dalam hal berkolaborasi dalam belajar, berdiskusi, berlatih, dan bermain peran terasa lebih hidup dan bersemangat, dengan bimbingan dari seorang guru. Tetapi karena waktu sangat terbatas maka diperlukan cara lain untuk bisa mengelola pembelajaran yang efisien dan efektif yaitu menggunakan platform pembelajaran berbasis e-learning seperti google classroom atau moodle.

Hal-hal yang berkaitan dengan share materi, diskusi online, chatting, penyelenggaraan evaluasi dapat dilakukan dengan baik pada Google Classroom. Menurut Ratnawati, H., \& Sulisworo, D (2021:138), "Google Classroom mampu mengatasi keterbatasan ruang dan waktu serta memudahkan pendidik untuk mengevaluasi dan memantau setiap kegiatan pembelajaran peserta didik sehingga membuat pembelajaran lebih efektif dan efisien". Pembelajaran online learning dengan memamfaatkan teknologi sebagai media pembelajaran dapat memberikan kemudahan dalam mengelola kelas dan membuat pembelajaran menjadi efektif dan efisien. Tantangan dalam pembelajaran online learning adalah kualifikasi dan kompetensi guru masalah mendasar di setiap tingkat pendidikan formal mengelola pembelajaran (Murniarti, 2020).

Google Classroom adalah platform besutan Google yang disediakan secara gratis untuk digunakan pada lembaga-lembaga non profit seperti sekolah dan untuk perorangan. Google Classroom membantu guru untuk membuat dan mengatur tugas kelas dengan cepat dan mudah, memberikan umpan balik kepada siswa langsung secara efisien, dan berkomunikasi bersama siswa tanpa terbatas oleh ruang dan waktu. Disamping itu Google Classroom terintegrasi dengan Google Drive sehingga manajemen file-file berupa vidio, materi ajar, absen siswa, nilai siswa, kuis-kuis, ulangan harian, evaluasi tengah semester, dan evaluasi akhir semester dapat kelola lewat 1 drive. Menurut Wijoyo, H., Riau, S. D., \& Maitreyawira, S. T. A. B. (2021:4), keunggulan dari Google Classroom sebagai Learning Management System (LMS), yaitu: 1) mudah membuat kelas dan settingannya sangat cepat; 2) hemat dan efisiensi waktu; 3) komunikasi dan diskusi sangat muda dilakukan; 4) data tersimpan pada google drive; 5) Berbagi sumber file yang efisien, praktis dan cepat.

Online Learning bukan tanpa kendala, menurut Junior, D. (2021:81) kekurangan belajar online learning yaitu: 1) peserta didik kesulitan mengikuti pembelajaran bagi mereka yang tidak mempunyai perangkat laptop atau smartphone yang memadai; 2) peserta didik kesulitan mengerjakan tugas-tugas jika jaringan internet tidak memadai; 3) tingkat kecurangan peserta didik dalam menyontek sangat tinggi, 4) biaya internet yang masih mahal, 5) pembelajaran kurang menarik karena tidak ada interaksi secara langsung. Dari beberapa pendapat ahli di atas dapat disintesakan bahwa dengan memamfaatkan Google Classroom sebagai learning management system, akan diperoleh beberapa mamfaat, sebagai berikut: 1) komunikasi dua arah guru-siswa sangat mudah dilakukan layaknya belajar dalam ruang kelas; 2) dapat menangani tugas administrasi pendidikan lebih cepat jika learning management system-nya tepat ; 3) proses mengajar/belajar dapat dilakukan di mana pun, kapan pun, dan dari perangkat mobile selama ada

Hendrik Palinggi, Witarsa Tambunan 
jaringan internet; 4) pengelolaan pembelajaran sangat hemat dan efisien dari aspek biaya dan waktu; 5) standar keamanan data memenuhi standar keamanan yang tinggi; 6) aplikasinya sangat mudah dioperasikan dan tidak akan mengalami kesulitan saat digunakan, 7) semua data terpusat pada satu drive.

\section{METODE PENELITIAN}

Metode yang digunakan dalam penelitian ini adalah metode kualitatif dengan pendekatan literatur review dan respon partisipan lewat google form kepada siswa-siswi dan guru-guru. Analisis data menggunakan pohon masalah, pohon sasaran, dan pohon solusi untuk mendeskripsi masingmasing indikator yang diteliti. Dari indikator yang diteliti didapatkan hubungan sebab akibat antar indikator penyebab masalah dan indikator yang bisa diintervensi guna menemukan format sistem manajemen pembelajaran terbaik untuk mencapai tujuan pendidikan yang efisen dan efektif. Adapun tujuan penelitian ini adalah mencari format terbaik sistem manajemen pembelajaran yang cocok digunakan di SMA Kristen Rantepao selama pandemi covid 19. Hasilnya dapat digunakan sebagai rekomendasi kepada tim manajemen sekolah dalam pengembangan sistem manajemen pembelajaran yang lebih baik dan dapat diimplementasikan guru-guru sebagai sistem manajemen pembelajaran dengan baik.

\section{HASIL DAN PEMBAHASAN}

Pola pembahasan dalam penelitian ini menggunakan analisis pohon masalah dan pohon sasaran dalam bentuk yang dinarasikan. Hasil temuan dikomperasikan dengan temuan pada penelitian sebelumnya guna mendapatkan pokok masalah dan mencari solusi yang tepat. Berdasarkan hasil observasi dan survei indikator yang diteliti dari siswa-siswa dan guru-guru di SMA Kristen Rantepao selama pembelajaran tatap muka terbatas pada masa pandemi covid 19 adalah:

Indikator persepsi siswa dan guru menggunakan google Classroom.

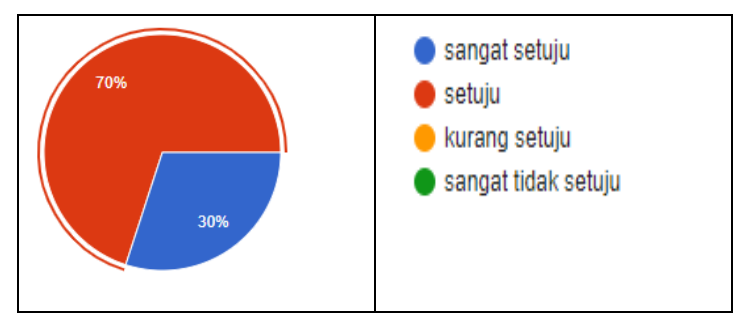

Gambar 1. Persepsi guru dan siswa dalam menggunakan google classroom.

Pada hasil survei persepsi siswa dan guru sama-sama mayoritas sangat setuju bahwa google classroom muda diakses dengan menggunakan handphone dan laptop dari mana dan kapanpun selama ada jaringan internet. Karena kemudahan google classroom diakses guru dan siswa dari mana dan kapanpun dengan menggunakan HP dan Laptop, maka menjadi aplikasi yang dapat digunakan guru dalam mengelola sistem pembelajaran tatap muka terbatas dalam hal administrasi pembelajaran.

Hal yang berbeda didapat ketika siswa ditanya, "Apakah Anda setuju kalau tatap muka di ganti dengan tatap muka virtual dengan menggunakan aplikasi seperti google meet atau teams?", mayoritas siswa mengatakan sangat tidak setuju. Alasannya, siswa lebih muda mengerti materi pembelajaran dengan tatap muka langsung guru-siswa di dalam ruang kelas.

Indikator persepsi siswa dan guru tentang efektifitas dan efisiensi dengan menggunakan google classroom. 


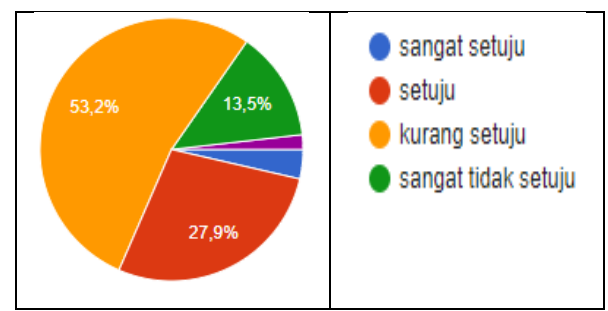

Gambar 2. Persepsi siswa dalam efektivitas dan efisiensi menggunakan google classroom.

Pada hasil observasi dan wawancara kepada beberapa siswa, diperoleh bahwa mayoritas siswa mengatakan belajar lebih efektif dan efisien jika pembelajaran dilakukan tatap muka langsung di dalam ruang kelas dibanding dengan belajar tatap muka secara virtual. Hal yang sama ditemukan pada persepsi guru, bahwa lebih efektif dan efisien jika materi ajar disampaikan langsung dalam ruang kelas.

Hasil yang berbeda didapat oleh Ratnawati, H., \& Sulisworo, dalam penelitian berjudul "D. Efektivitas E-Learning Berbasis LMS Google Classroom Dengan Strategi Discovery Learning Materi Fluida Statis SMA". Dalam penelitiannya diperoleh hasil bahwa:" pembelajaran Google Classroom dengan strategi Discovery pada materi fluida statis efektif dapat digunakan, dan bisa dilakukan pada mata pelajaran lain. Bahkan juga berbeda dengan landasan teori yang digunakan menurut pendapat Wijoyo, H., Riau, S. D., \& Maitreyawira, S. T. A. B. (2021:4), bahwa keunggulan belajar dengan menggunakan google classroom salah stunya efektif dan efisien. Hasil berbeda diperoleh di SMA Kristen Rantepao karena terdiri dari siswa-siswi yang berasal dari daerah-daerah pedalaman yang jaringan internetnya masih morat-marit dan juga dari orang tua dengan golongan tingkat ekonomi keluarga yang beragam. Sehingga sangat menyulitkan guru dalam meyampaikan materi lewat google classroom.

Indikator persepsi kesulitan guru dalam menggunakan google classroom.

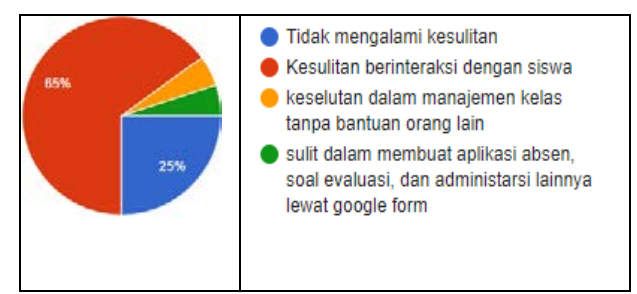

Gambar 3. Persepsi guru dalam kesulitan menggunakan google classroom.

Dari data diperoleh bahwa guru umumnya kesulitan berinteraksi dengan siswa lewat google classroom dan ada beberapa orang masih kesulitan dalam manajemen kelas dengan menggunakan google classroom. Hal serupa ketika disurvei kepada siswa, mayoritas siswa mengatakan sangat kesulitan berinteraksi dengan guru lewat google classroom. Dari 3 indikator di atas dapat diperoleh hasil sebagai berikut: 1) google classroom hanya efektif dan efisien pada sistem manajemen pembelajaran berupa sharing materi, pemberian tugas, pengembalian tugas, dan evaluasi; 2) Pembelajaran tatap muka terbatas di dalam kelas sangat efektif dan efisien untuk pemyampaian materi ajar dan interaksi dengan siswa.

\section{KESIMPULAN}

Kesimpulan

Hasil pembahasan dan kajian teori dapat membuktikan bahwa kombinasi google clasroom dan tatap muka terbatas selama pandemi covid 19 dapat efektif dan efisien dari segi proses, biaya, dan waktu untuk sistem manajemen pembelajaran jika guru menggunakan:1) tatap muka di dalam 
kelas untuk menyampaikan materi dan berinteraksi dengan siswa, dan 2) semua administrasi pembelajaran (absen, sharing materi, pemberian tugas, evaluasi) semua dilakukan lewat google classroom.

Implikasi

Tatap muka terbatas terasa sangat tidak efektif dari segi waktu untuk menyampaikan materi ajar dengan alokasi waktu yang hanya 60 menit per bidang studi. Waktu yang sangat terbatas seperti ini harus dimamfaatkan semaksimal mungkin oleh guru dalam menjelaskan materi-materi ajar dan berinteraksi dengan siswa didalam kelas.

Hal-hal yang berkaitan dengan administarsi pembelajaran seperti sharing materi ajar, absen, diskusi, dan evaluasi dapat dilakukan lewat google classroom. Aplikasi google classroom sangat bermamfaat untuk mengelolah kelas secara daring. Sehingga kombinasi kedua sistem yang telah diuraikan di atas dapat menjadi sistem manajemen pembelajaran yang baik.

Saran

Supaya sistem manajemen pembelajaran berjalan sesuai harapan selama masa pandemi covid -19 maka disarankan: 1) kepada tim manajemen sekolah untuk membuat pelatihan-pelatihan pemamfaatan TIK dalam proses belajar mengajar di sekolah terutama memamfaatkan google clasroom; 2) sarana dan prasarana sekolah ditingkatkan terkait dengan belajar daring.

\section{DAFTAR PUSTAKA}

1. Aldiab. A., Chowdhury, H., Kootsookos, A., Alam, F., \& Allhibi, H. (2019). Utilization of Learning Management Systems (LMSs) in higher education system: A case review for Saudi Arabia. Energy Procedia, 160, 731-737.

2. Alfina. O. (2020). Penerapan Lms-Google Classroom Dalam Pembelajaran Daring Selama Pandemi Covid-19. MAJALAH ILMIAH METHODA, 10(1), 38-46.

3. Azhar. K. A., \& Iqbal, N. (2018). Effectiveness of Google classroom: Teachers' perceptions. Prizren Social Science Journal, 2(2), 52-66.

4. Bernadetha Nadaek (2019). Manajemen Sumber Daya Manusia Pendidikan Era Industri 4.0. Jakarta- UKI Press

5. Cheng, M., \& Yuen, A. H. K. (2018). Student continuance of learning management system use: A longitudinal exploration. Computers \& Education, 120, 241-253.

6. Erwinsyah, A. (2017). Manajemen Pembelajaran Dalam Kaitannya Dengan Peningkatan Kualitas Guru. Tadbir: Jurnal Manajemen Pendidikan Islam, 5(1), 69-84.

7. Fakhrurrazi, F. (2018). Hakikat pembelajaran yang efektif. At-Tafkir, 11(1), 85-99.

8. Ghazal, S., Aldowah, H., \& Umar, I. (2017, April). Critical factors to learning management system acceptance and satisfaction in a blended learning environment. In International Conference of Reliable Information and Communication Technology (pp. 688-698). Springer, Cham.

9. Holloway, I., \& Todres, L. (2003). The status of method: flexibility, consistency and coherence. Qualitative Research, 3(3), 345-357. 
10. Holmes, K. A., \& Prieto-Rodriguez, E. (2018). Student and Staff Perceptions of a Learning Management System for Blended Learning in Teacher Education. Australian Journal of Teacher Education, 43(3), 21-34.

11. Junior, D. (2021). Implementasi Metode E-Learning Melalui Aplikasi Google Classroom Dalam Mata Pelajaran Geografi Di Sman 1 Bantarkawung. PROCEEDING UMSURABAYA, 1(1).

12. Komalasari, R. (2020). Manfaat Teknologi Informasi dan Komunikasi di Masa Pandemi Covid 19. TEMATIK-Jurnal Teknologi Informasi Dan Komunikasi, 7(1), 38-50.

13. Muhardi, M., Gunawan, S. I., Irawan, Y., \& Devis, Y. (2020). Design Of Web Based LMS (Learning Management System) in SMAN 1 Kampar Kiri Hilir. Journal of Applied Engineering and Technological Science (JAETS), 1(2), 70-76.

14. Shiddiq, M. Z., Marijono, M., \& Imsiyah, N. (2018). Pengaruh Pembelajaran Tatap Muka Terhadap Kemampuan Afektif Warga Belajar Pendidikan Kesetaraan Paket C Di PKBM Suaka Anak Negeri Jember. Learning Community: Jurnal Pendidikan Luar Sekolah, 2(1), 14-16.

15. Ouadoud, M., Nejjari, A., Chkouri, M. Y., \& El-Kadiri, K. E. (2017, October). Learning management system and the underlying learning theories. In Proceedings of the Mediterranean Symposium on Smart City Applications (pp. 732-744). Springer, Cham.

16. Ratnawati, H., \& Sulisworo, D. Efektivitas E-Learning Berbasis LMS Google Classroom Dengan Strategi Discovery Learning Materi Fluida Statis SMA. Jurnal Penelitian Pendidikan Fisika, 6(2), 137-145.

17. Ouadoud, M., Nejjari, A., Chkouri, M. Y., \& El-Kadiri, K. E. (2017, October). Learning management system and the underlying learning theories. In Proceedings of the Mediterranean Symposium on Smart City Applications (pp. 732-744). Springer, Cham.

18. Kumar, J. A., \& Bervell, B. (2019). Google Classroom for mobile learning in higher education: Modelling the initial perceptions of students. Education and Information Technologies, 24(2), 1793-1817.

19. Sudarsana, I. K., Putra, I. B. M. A., Astawa, I. N. T., \& Yogantara, I. W. L. (2019, March). The use of Google classroom in the learning process. In Journal of Physics: Conference Series (Vol. 1175, No. 1, p. 012165). IOP Publishing.

20. SS, Y. S. D., \& SE, M. (2013). Manajemen pembelajaran dalam upaya meningkatkan mutu pendidikan. Jurnal Mimbar Bumi Bengawan, 6(13). 